\title{
Seasonal variations of auxin and gibberellin A4 levels in cambial-region tissues of three conifers (Pinus elliottii, Chamaecyparis obtusa, and Cryptomeria japonica) with inherently different wood densities
}

\author{
Yoshio Kijidani ${ }^{1 *}$, Taku Tsuyama ${ }^{1}$ and Katsuhiko Takata ${ }^{2}$
}

\begin{abstract}
We previously reported the species-specific annual ring formation characteristics of three conifers (slash pine (Pinus elliottii), hinoki (Japanese cypress, Chamaecyparis obtusa) and sugi (Japanese cedar, Cryptomeria japonica)) grown in the same stand over 2 years. We found that the species-specific annual ring formation characteristics affected the inherent difference in wood density among these conifers (slash pine > hinoki > sugi). Plant hormones in cambialregion tissues were believed to affect annual ring formation. However, seasonal variation of the amounts of plant hormones in cambial-region tissues had only been examined in a few tree species. In this study, as the first step to elucidating the role of plant hormones in annual ring formation in conifers, we report the seasonal variations of the auxin (indole acetic acid, IAA) and gibberellin A4 (GA4) levels in cambial-region tissues and their effects on annual ring formation in three conifers (slash pine, hinoki, and sugi) with inherently different wood densities.

Sugi (small wood density) had significantly higher levels of IAA and formed more tracheids in the early season than in the late season, although slash pine (large wood density) had higher levels of IAA and formed significantly more tracheids in the late season than in the early season. Hinoki (intermediate wood density) had constant IAA levels and formed a constant number of tracheids throughout the season. There were significant positive correlations between the levels of IAA in cambial-region tissues and the number of tracheids formed during late season in the two conifer species. A close relationship was observed between the seasonal ratio of the IAA levels (late/early season) and wood density. No consistent trend in the change in the level of IAA during the transition from earlywood to latewood formation was recognized among the three conifers. The IAA levels in slash pines were significantly higher than those in sugi and hinoki. The GA4 levels had no significant effect on number of tracheids formed in the three conifers. These results suggest that the species-specific seasonal variation patterns of the IAA levels might lead to the inherent differences in wood density among these three conifers through species-specific characteristics in the formation of annual rings.
\end{abstract}

Keywords: Slash pine, Japanese cypress, Japanese cedar, IAA, Wood density, GA4

\footnotetext{
*Correspondence: kijiyo@cc.miyazaki-u.ac.jp

1 Division of Forest and Environmental Science, Faculty of Agriculture,

University of Miyazaki, Miyazaki 889-2192, Japan

Full list of author information is available at the end of the article
}

\section{Introduction}

Softwood is one of the most important renewable resources in the world. It is mainly used as a material in the structural components of wooden structures. Therefore, it is important that the mechanical properties and 
dimensional stability of softwoods be well understood. It has been reported that the wood density and the microfibril angle (MFA) in the $\mathrm{S}_{2}$ layer of the cell wall can explain the variation in the mechanical properties of commercially important softwoods and hardwoods [1-4]. The wood density and MFA were also important parameters in determining the dimensional stability of sugi (Japanese cedar, Cryptomeria japonica) [5]. Tracheids in softwoods are formed through annual ring formation by cambium. The variation of annual ring formation in cambial-region tissues according to the season could affect the variations in wood density and MFA. Therefore, we reported the species-specific characteristics of annual ring formation in three conifer species, namely slash pine (Pinus elliottii; wood density in mature wood: $450-500 \mathrm{~kg} / \mathrm{m}^{3}$ ), hinoki (Japanese cypress, Chamaecyparis obtusa; wood density in mature wood: $400 \mathrm{~kg} / \mathrm{m}^{3}$ ) and sugi (Japanese cedar, C. japonica; wood density in mature wood: $350 \mathrm{~kg} /$ $\mathrm{m}^{3}$ ) grown in the same stand. We focused on latewood formation, which affects wood density [6]. In the slash pine, which has a high wood density, cell division during latewood formation was more active than in hinoki, with intermediate wood density, or sugi, with a relatively low wood density [6]. It was assumed that the active latewood formation in the slash pine induced high wood density in spite of its large radial growth rate. However, the factors that induced these species-specific characteristics of annual ring formation in these three conifer species remain unclear.

Previous studies on pine trees have revealed that auxin (Indole acetic acid, IAA) is an important regulator of annual ring formation [7-12]. Another study on the plant hormones in conifers was conducted to precisely elucidate the variation in the wood properties of sugi. There was a positive correlation between IAA levels and the number of tracheids formed during the active season of cambium in sugi [13]. The effects of gibberellins on annual ring formation have also been reported, especially in broad-leaved trees. A quantitative study showed that gibberellin A1 and gibberellin A4 (GA4) were located in the zone of expansion in the xylem cells of aspen trees [14]. A study in which gibberellin A3 and inhibitors of the synthesis of gibberellin were applied found that gibberellin plays an important role in the tension wood formation of Acacia mangium seedlings [15]. On the other hand, our previous study on sugi trees showed that there was no direct effect of GA4 on tracheid formation [13]. In angiosperm trees, gibberellins might play an important role in xylem cell differentiation, although their role in conifers might be unclear. However, there have been very few quantitative studies on the endogenous gibberellins in conifers. To understand the effects of annual ring formation on wood density in conifers, more information is needed on the role of plant hormones in annual ring formation in conifers that have different annual ring formation characteristics and inherently different wood density from sugi, such as slash pine and hinoki [6].

The slash pine is commercially important to plantations in the southeastern United States because of its fast growth and the excellent utility of its wood [16]. Fewer studies on annual ring formation and wood properties have been done on the slash pine. The annual ring formation in slash pine grown in the most southern areas took place from February to December, while latewood formation occurred from July to December [17]. The dormant period of cambium was very short [17]. However, young slash pine families had relatively short periods of annual ring formation (from March to October), and active cell division in the cambium was observed in the early season [18]. Studies of a slash pine tree-breeding program revealed that the growth rate was affected by the interaction of genetic and environmental factors, and that fusiform rust infections and wind damage reduced the growth rate [19]. For improvement of juvenile wood properties, stiffness of trunk in slash pine clones was evaluated, and a correlation between tree height and trunk stiffness was found [20]. It was reported that low initial tree density reduced the strength of lumber and fertilization increased the wood volume 1.8- to 2.2-fold in slash pine [21, 22].

Hinoki is one of the important conifers grown on plantations in Japan. Hinoki has been used for structural applications because of its superior mechanical properties and durability. Studies have been done on the annual ring formation and wood properties of hinoki. The xylem formation activity in hinoki was shown to be relatively constant throughout all of the seasons, although slash pine and sugi actively formed tracheids during late season and early season, respectively [6]. The growth traits affected the MFA, wood density, and mechanical properties of hinoki [23]. Previous studies have reported on the significant differences in the anatomical parameters of wood properties (wood density and MFA) [24] and in the termite resistance and color of heartwood [25] among hinoki half-sib families. However, as far as we know, there has been no precise study of the role of plant hormones in annual ring formation, especially in late season, which affects the latewood percentage and wood density in these conifers.

In this study, as the first step to elucidating the role of plant hormones in annual ring formation in conifers, we reported the seasonal variation of the IAA and GA4 levels in cambial-region tissues and its effects on the annual ring formation in three conifer species (slash pine, hinoki, and sugi) grown in the same stand. This is the first study that revealed the seasonal variation of plant hormones 
in cambial-region tissues of these three conifer species grown in the same stand. This study helps to elucidate the species-specific characteristics of annual ring formation and the inherent differences in the wood density of conifers.

\section{Materials and methods}

Sample trees and samples used for analysis of plant hormones and annual ring formation

The 33-year-old sugi trees, 33-year-old hinoki trees, and 57-year-old slash pine trees shown in Table 1 were used as sample trees. These sample trees were grown in neighboring plots in the same stand. These plots were established in the experimental forest at the University of Miyazaki. The sugi and hinoki plots were used for lumber production, and the slash pine plot was used for exhibition. The same silvicultural practices (thinning was performed, pruning was not, and the initial tree density was 2500-3000 trees/ha) were carried out in all the plots. Four trees with no visible defects were selected for each species. The plots used in this study were located in the western part of Miyazaki city. The average annual temperature and precipitation (20112012) in Miyazaki city were $17.3{ }^{\circ} \mathrm{C}$ and $2891 \mathrm{~mm}$, respectively. The altitude of the experimental forest at the University of Miyazaki ranged from 100 to $300 \mathrm{~m}$. The diameter of the trees at breast height $(\mathrm{DBH})$ and the tree height were measured with a tape measure and ultrasonic hypsometer (Vertex III, Haglof, Inc.), respectively. To measure the levels of IAA and GA4 in cambial-region tissues, samples $(2 \mathrm{~cm}(\mathrm{~T}) \times 3 \mathrm{~cm}(\mathrm{~L}) \times 1 \mathrm{~cm}$ (R)) of cambial-region tissues sandwiched between the outer bark and the outermost xylem were obtained from the sample trees, as listed in Table 1 . The samples were obtained from a point $1.2 \mathrm{~m}$ above the ground in each tree in May, July, September, and November in 2011 and in April in 2012 ( 3 species $\times 4$ trees $\times 5$ sampling months, for a total of 60 samples). Immediately after collection, the samples were stored in a deep freezer $\left(-80^{\circ} \mathrm{C}\right)$ before extraction was performed.

\section{Analysis of plant hormones}

IAA and GA4 in cambial-region tissues were identified and quantified by liquid chromatography/mass spectrometry (LC/MS) according to the method shown in a previous study [13]. Samples were extracted by methanol with deuterium-labeled IAA (D2-IAA, 97\% content; Sigma Co., Ltd) and deuterium-labeled GA4 (D2-GA4, 90\% content; Olchemim, Ltd) as internal standards. The extracts were purified using reverse-phase cartridges (Sep-pack cartridge, C18 $500 \mathrm{mg}$, Waters) and then quantified by LC/MS (Ultimate 3000, Q-exactive, Thermo Fisher Scientific). The column was an Atlantis T3 $(100 \times 2.1 \mathrm{~mm}, 3 \mu \mathrm{m}$, Waters $)$; as the mobile phase, methanol containing $0.1 \%(\mathrm{v} / \mathrm{v})$ formic acid and distilled water containing $0.1 \%(\mathrm{v} / \mathrm{v})$ formic acid was used, and the flow rate was $0.2 \mathrm{ml} / \mathrm{min}$ for both IAA and GA4. Detection and quantification were carried out using Q-exactive operated in the positive (IAA) and negative (GA4) ion, targeted-SIM (Selected Ion Monitoring) mode using calibration curves with D2-IAA and D2-GA4 as internal standards. As described in a previous study [26], the levels of IAA and GA4 in the cambial-region tissues are shown as amounts (ng) per cambium area $\left(\mathrm{L} \times \mathrm{T} \mathrm{cm}^{2}\right)\left(\mathrm{ng} / \mathrm{cm}^{2}\right)$.

Table 1 Sample trees

\begin{tabular}{|c|c|c|c|c|c|c|}
\hline Species & No. & Age & $\begin{array}{l}H \\
(\mathrm{~m})\end{array}$ & $\begin{array}{l}\text { DBH } \\
(\mathrm{cm})\end{array}$ & $\begin{array}{l}\text { H/D ratio } \\
(\%)\end{array}$ & $\begin{array}{l}\text { Wood density } \\
\left(\mathrm{kg} / \mathrm{m}^{3}\right)\end{array}$ \\
\hline \multirow{4}{*}{$\begin{array}{l}\text { Sugi } \\
\text { (Cryptomeria japonica) }\end{array}$} & 1 & \multirow[t]{4}{*}{33} & 16.0 & 22.6 & 70.8 & 303 \\
\hline & 2 & & 15.7 & 22.1 & 70.9 & 298 \\
\hline & 3 & & 14.8 & 18.5 & 80.1 & 375 \\
\hline & 4 & & 16.4 & 22.9 & 71.5 & 303 \\
\hline \multirow{4}{*}{$\begin{array}{l}\text { Hinoki } \\
\text { (Chamaecyparis obtusa) }\end{array}$} & 1 & \multirow[t]{4}{*}{33} & 12.1 & 15.6 & 77.5 & 429 \\
\hline & 2 & & 12.6 & 13.7 & 92.0 & 433 \\
\hline & 3 & & 11.6 & 13.4 & 86.7 & 394 \\
\hline & 4 & & 11.5 & 12.1 & 95.0 & 406 \\
\hline \multirow{4}{*}{$\begin{array}{l}\text { Slash pine } \\
\text { (Pinus elliottii) }\end{array}$} & 1 & \multirow[t]{4}{*}{57} & 22.2 & 44.9 & 49.4 & 543 \\
\hline & 2 & & 26.1 & 59.9 & 43.6 & 523 \\
\hline & 3 & & 23.0 & 35.0 & 65.7 & 555 \\
\hline & 4 & & 27.7 & 50.0 & 55.4 & 475 \\
\hline
\end{tabular}

$H$ tree height, $D B H$ diameter at breast height, $H / D$ ratio height-to-diameter ratio

The wood density was measured on the samples with 2-4 outer rings (including the current rings being formed in 2011) 


\section{Analysis of annual ring formation and measurement} of wood density

To analyze annual ring formation, we prepared $10-\mu \mathrm{m}$-thick cross-sections of the xylem samples to use in the analysis of plant hormones after methanol extraction. Lignified tracheids remained in the xylem samples after methanol extraction, although phloem tissues, cambium, and unlignified tracheids were removed from the xylem samples by the extraction procedure. The number of formed lignified tracheids was obtained by averaging 10 measurements made at different positions in the cross-section as observed using a light microscope. We examined the number of lignified tracheids formed in each test period as shown in Fig. 1. These test periods included five periods from the initiation of annual ring formation to May in 2011 (test period I), from May to July in 2011 (test period II), from July to September in 2011 (test period III), from September to November in
2011 (test period IV), and from the initiation of annual ring formation to April in 2012 (test period V). According to the method described in our previous study [6], we determined the month of transition from earlywood formation to latewood formation.

By the sectioning of the samples before the samples were stored in a deep freezer, more precise information on cell divisions and cell differentiation could be obtained for the analysis for annual ring formation. And in combination with analysis of radial distribution of plant hormones in cambial-region tissues [12], more precise role of plant hormones in annual ring formation might be clarified. However, according to our previous study [13], we examined the relationships between total IAA levels in samples and number of lignified tracheids in this study. And the injuries induced by sampling in the stems might affect annual ring formation in the next sampling position. Therefore, the five sampling positions around the

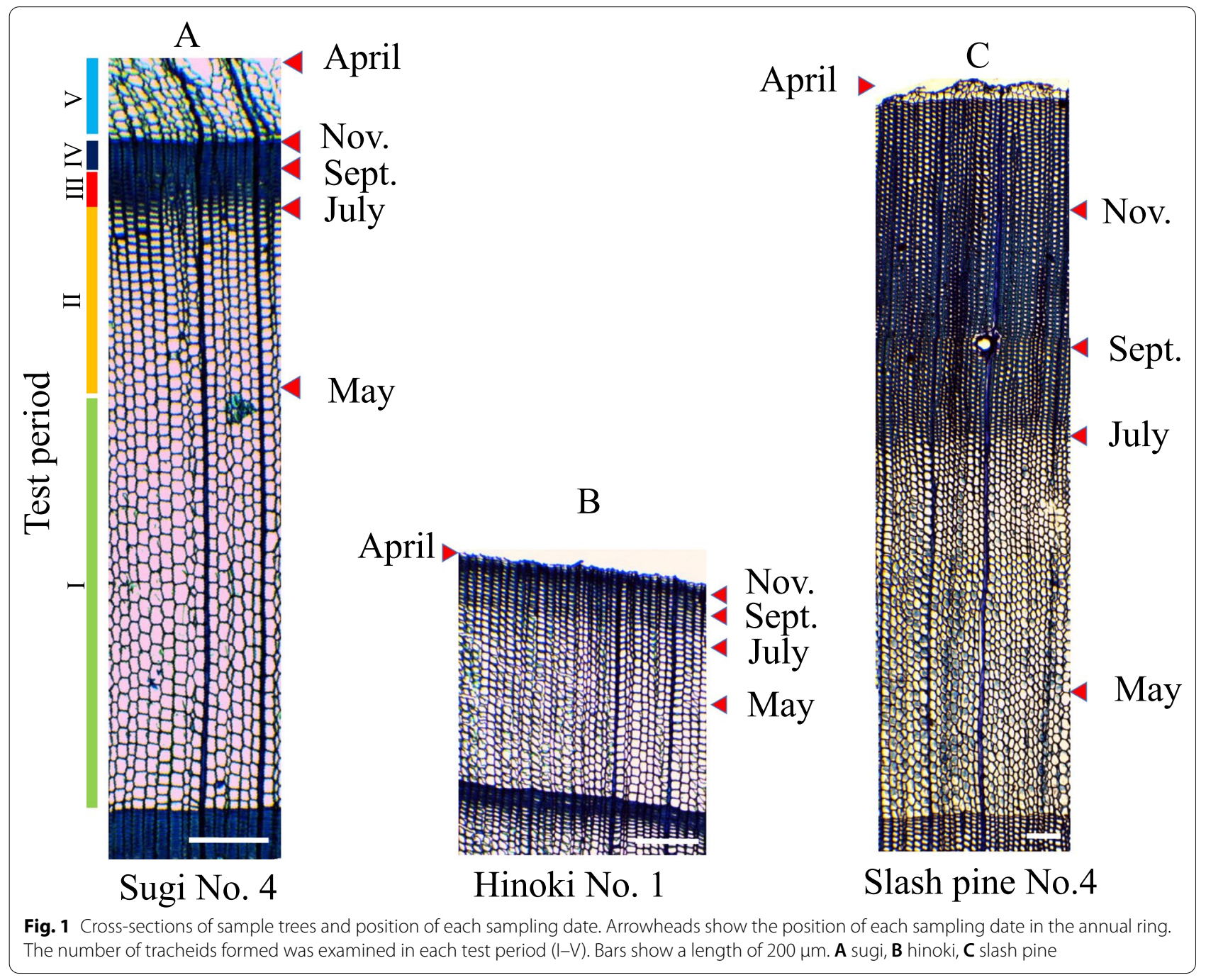


stems had a distance from each other for decrease of the effects of injuries. Large distance between the sampling positions might decrease the accuracy of evaluation for annual ring formation. Therefore, we evaluate the annual ring formation by the test period based on adjacent two sampling positions.

The xylem samples collected in April 2012 for the analysis of plant hormones were used for measurements of wood density. The xylem samples had 2-4 outer annual rings including the current ring formed in 2011. The wood density was calculated from the green volume and kiln dry weight.

\section{Results and discussion}

\section{Seasonal variation of annual ring formation among three conifers}

The typical species-specific annual ring formation patterns can be observed in the cross-sections shown in Fig. 1. Slash pine No. 4 formed a larger number of tracheids after November (Fig. 1C), and had a shorter dormant period of the cambium in comparison with sugi No. 4 (Fig. 1A) and hinoki No. 1 (Fig. 1B). As shown in

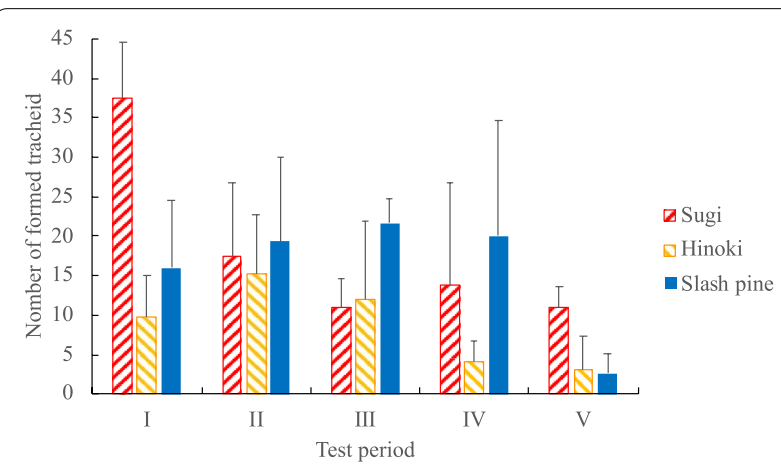

Fig. 2 Annual ring formation in three conifers. Test periods I-V refer to the periods shown in Fig. 1. Data are means \pm SD ( $n=3$ or 4$)$
Fig. 1, the initiation of latewood formation in all of the sample trees was observed in July. The numbers of lignified tracheids formed in each test period in the three types of conifers are shown in Fig. 2. In this study, we did not examine the initiation and cessation of annual ring formation because we assumed, based on our previous study on sugi, that IAA did not relate to initiation and cessation, but rather to cell division during annual ring formation [13]. Each test period in Fig. 2 included about two months of annual ring formation except test periods I and V. Based on our preliminary research, the three conifer species in this stand initiated annual ring formation in March. Therefore, test period I would include about two months of annual ring formation, and test period $\mathrm{V}$ would include one month of the next annual ring formation. As shown in Fig. 1 and Fig. 2, species-specific characteristics of annual ring formation were recognized in the three conifers. Larger numbers of tracheids were formed in the early season (test periods I and V) in sugi than in the late season. Relatively constant numbers of tracheids were formed throughout three of the periods (test periods I-III) in hinoki trees. Active xylem formation was not recognized in the early season (test periods I and V) in hinoki. In slash pine, the number of tracheids formed was also constant throughout all of the periods. However, the number of tracheids formed in slash pine in the late season (test periods III and IV) was greater than in sugi and hinoki. However, slash pine No. 2 showed active tracheid formation in the early season, with 34 tracheids formed in test periods $\mathrm{I}+\mathrm{V}$ and 24 tracheids formed in test periods II-IV. Based on the slash pine results in our previous study [6], we assumed that slash pine No. 2 did not show a typical annual ring formation pattern for that species. Therefore, we excluded the data of slash pine No. 2 from all of the figures and from Table 2.

Table 2 Characteristics of annual ring formation and plant hormones among three conifer species

\begin{tabular}{|c|c|c|c|c|c|c|c|c|c|c|}
\hline \multirow[t]{2}{*}{ Species } & \multirow[t]{2}{*}{$n$} & \multicolumn{3}{|c|}{ Number of tracheids formed } & \multicolumn{3}{|c|}{ IAA $\left(\mathrm{ng} / \mathrm{cm}^{2}\right)$} & \multicolumn{3}{|c|}{$\mathrm{GA} 4\left(\mathrm{ng} / \mathrm{cm}^{2}\right)$} \\
\hline & & E & $\mathbf{L}$ & $p$ & $\mathrm{E}$ & $\mathbf{L}$ & $p$ & $\mathrm{E}$ & $\mathbf{L}$ & $p$ \\
\hline Sugi & 4 & $24(15)$ & 14(9) & 0.07 & $52.2(16.8)$ & $31.3(7.8)$ & 0.001 & $1.9(1.9)$ & $0.8(0.4)$ & 0.06 \\
\hline Hinoki & 4 & $6(6)$ & $10(8)$ & 0.24 & $37.9(12.5)$ & $36.5(13.1)$ & 0.81 & $1.0(0.5)$ & $1.8(2.4)$ & 0.38 \\
\hline Slash pine & 3 & 9(9) & $20(9)$ & 0.04 & $101.3(37.5)$ & $126.4(55.8)$ & 0.36 & $1.2(0.4)$ & $1.6(1.2)$ & 0.46 \\
\hline
\end{tabular}

E early season, $L$ late season, $p p$-value of $t$ test

The significant difference between $\mathrm{E}$ and $\mathrm{L}$ was examined by $t$ test

The numbers of tracheids formed in $\mathrm{E}$ are the means for each species in test periods I and $\mathrm{V}$

The numbers of tracheids formed in Lare the means fore ach species in test periods II-V

ThelAA and GA4 data in E are the means for each species in Mayandthe following April

The IAA and GA4 data in $L$ are the means foreach species in July-November

Data in parentheses are standard deviations 
As shown in Table 2, average number of tracheids formed during late season was significantly greater than the number formed during early season in slash pine $(t$ test, $p<0.05)$, but the opposite tendency was observed in sugi ( $t$ test, not significant, $p=0.07)$. The average numbers of tracheids formed during early season and late season were almost the same in hinoki. These results, shown in Fig. 2 and Table 2, were consistent with our previous study [6]. As described in the "Introduction" section of the present study, the wood densities of mature wood in slash pine, hinoki, and sugi were $450-500 \mathrm{~kg} / \mathrm{m}^{3}, 400 \mathrm{~kg} /$ $\mathrm{m}^{3}$, and $350 \mathrm{~kg} / \mathrm{m}^{3}$, respectively [6], and the wood density of the sample trees in this study (Table 1) was consistent with the results of our previous study [6]. From these results, it was assumed that active tracheid formation in the late season induced greater wood density.

\section{Seasonal variation in levels of plant hormones in cambial-region tissues}

The levels of IAA in cambial-region tissues in each season are shown in Fig. 3. As shown in Fig. 3, it was recognized that there were species-specific characteristics in the seasonal variation of the IAA levels in the three conifers. The IAA levels in sugi were relatively larger in May and in the following April than in

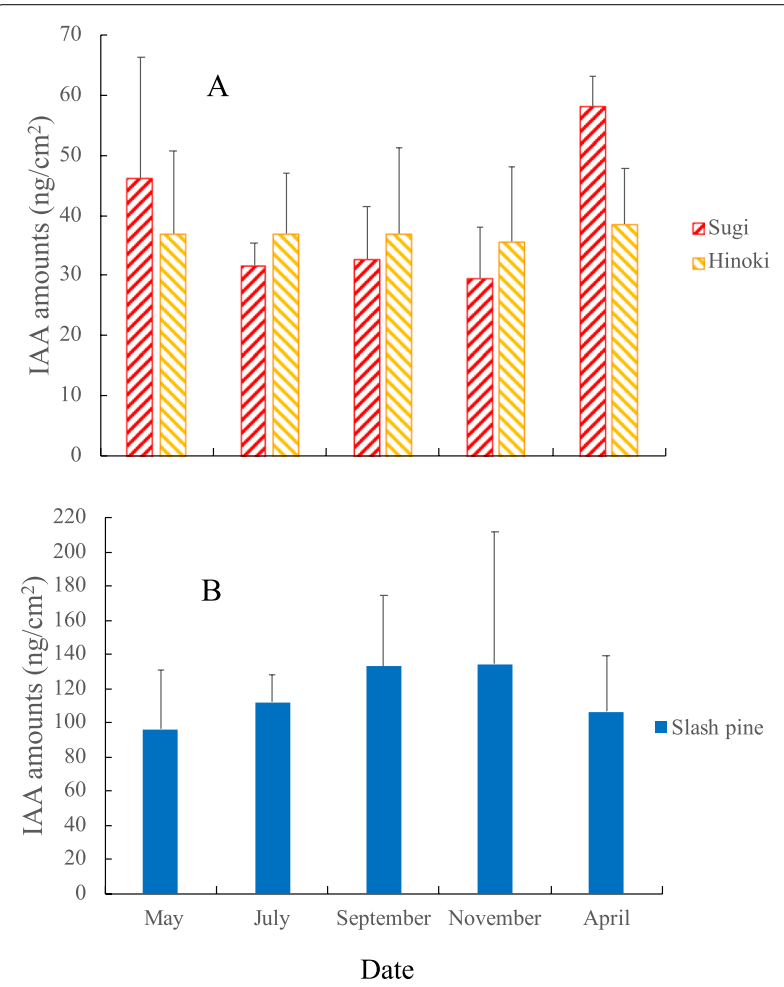

Fig. 3 Seasonal variation of IAA levels in three conifers. A Sugi and hinoki; $\mathbf{B}$ slash pine. Data are means \pm SD ( $n=3$ or 4$)$ the late season. The IAA levels in hinoki were relatively constant throughout the growing season, although there were relatively large variations among trees. The IAA levels in slash pine in the late season were relatively larger than those in the early season. As shown in Table 2, the average IAA level during early season was significantly larger than that during late season in sugi ( $t$-test, $p<0.01$ ), although the opposite trend was observed in slash pine. The average IAA levels during early season and late season were almost the same in hinoki. It was also demonstrated that the IAA levels in slash pine were significantly greater than those in sugi and hinoki (multiple comparison test (Tukey HSD), $p<0.01$, Fig. 3, Table 2). Therefore, we assumed that slash pine had genetically higher levels of IAA than sugi and hinoki, because, as these three conifers grew in the same stand, the environmental differences among the samples should have been small. The IAA levels in slash pine obtained in this study were as large as the IAA levels previously reported in Pinus densiflora (20 years old, September) [27] and Pinus sylvestris (20 years old, May to August [28]; 43 years old, July [12]). IAA levels in cambial-region tissues that are higher than those in sugi and hinoki might be common in pine trees. However, the GA4 levels in slash pine were not greater than those in sugi and hinoki (Fig. 4). As shown in Table 2 and Fig. 4, the GA4 levels in cambial-region tissues did not show significant species-specific seasonal variation, although the average GA4 level during early season was relatively larger than that during late season in sugi $(t$-test, $p=0.06)$. From these results, it was recognized that there were species-specific seasonal variation patterns in the IAA levels in these three conifer species with inherently different wood densities.

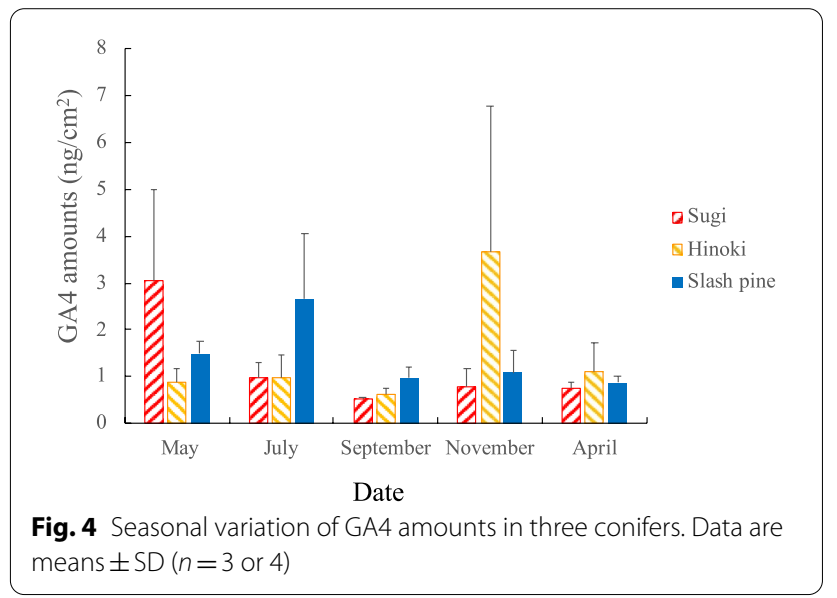




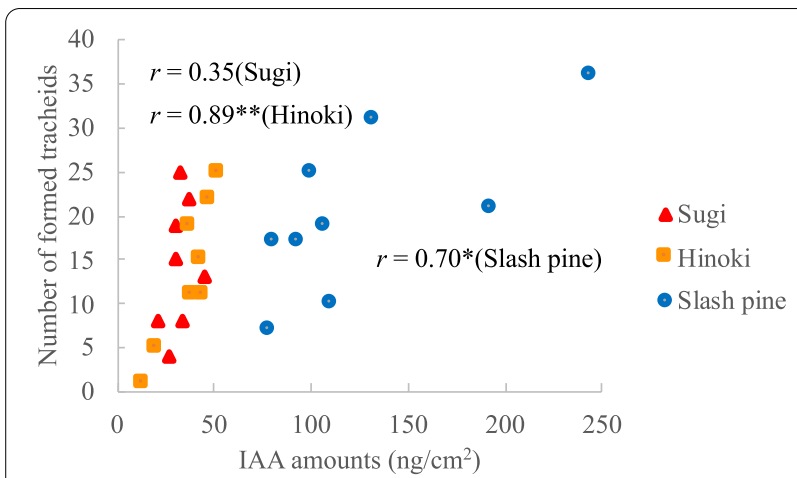

Fig. 5 Relationships between IAA levels and tracheid formation in three conifers during late season. Sugi and hinoki data were from July and September, and slash pine data were from July, September, and November. For example, the plotted data for July include the IAA levels in July and the number of tracheids formed in test period II. ${ }^{* *} p<0.01,{ }^{*} p<0.05$

\section{The role of plant hormones in annual ring formation and their effect on the inherent difference in wood density among three conifers}

To elucidate the role of plant hormones in late season, the relationships between IAA levels and the number of tracheids formed during late season are shown in Fig. 5. Annual ring formation in November in sugi and hinoki was close to cambium dormancy, although that in slash pine was still active (Fig. 1). Therefore, we used the data from July and September for sugi and hinoki, and the data from July, September, and November for slash pine in Fig. 5. There were significant positive correlations between the IAA levels and the number of tracheids formed in hinoki $(r=0.89, p<0.01)$ and slash pine $(r=0.70, p<0.05)$ during late season, although no significant positive relation in sugi $(r=0.35)$, suggesting that IAA played a role in cell division during late season in two conifers. In our previous study, although IAA had significant positive effects on cell divisions, closer correlations were recognized in early season than in late season [13]. As shown in Fig. 5, sugi and hinoki might need less IAA than slash pine to produce the same number of lignified tracheids. The sensitivity of cambium on IAA levels might differ among species.

In early season, there were positive relations between IAA levels and the number of tracheids formed in sugi and hinoki, although no positive relations were observed in early season in slash pine in the following April (Fig. 6, $r=0.66,0.52$ and -0.003 , respectively). Although there was no significant correlation in Fig. 6, sugi had a larger correlation coefficient between IAA levels and the number of tracheids formed in the following April than hinoki and slash pine. As shown in Fig. 6, sugi and hinoki might need less IAA than slash pine to produce the same

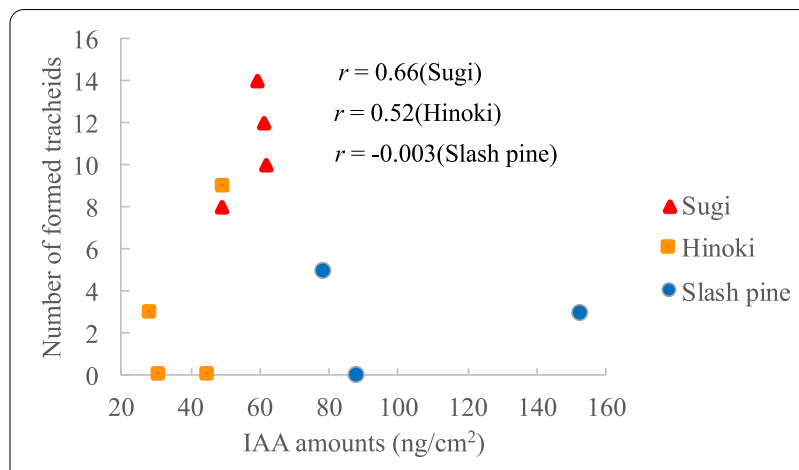

Fig. 6 Relationships between IAA levels and tracheid formation in three conifers during early season. Sugi and hinoki data were from samples collected the following April. The plotted data represent the IAA levels in the following April and the number of tracheids formed in test period $\mathrm{V}$

number of lignified tracheids. Even in early season, the sensitivity of cambium on IAA levels might differ among species. As previously noted, we did not examine the initiation of annual ring formation. Therefore, the number of days in the test periods that included early season (periods I and V) might have been different among the sample trees, and these possible differences in the test period could have affected the significance of the correlations between IAA levels and the number of tracheids formed during early season. More precise studies on early season are needed.

There was no significant correlation between GA4 levels and number of tracheids formed during late season among the three conifer species (data not shown). In this study, the transition from earlywood to latewood in the three conifers occurred in July (Fig. 1). However, no consistent trend in the change in IAA levels in the three conifers was recognized. Previous studies have focused on the relationship between IAA levels in cambial-region tissues and the transition from earlywood to latewood. The application of IAA to a young red pine (Pinus resinosa) producing latewood tracheids induced the formation of earlywood [9].The transition from earlywood to latewood occurred concurrently with the decrease in IAA levels in cambial-region tissues in $P$. densiflora [11]. The decrease in IAA levels might induce the transition from earlywood to latewood. However, studies with conflicting results have also been reported. The IAA amounts did not change with latewood initiation in P. sylvestris [29]. A previous study on sugi revealed that IAA had a positive correlation with the number of tracheids formed and no relation with the cross-sectional dimensions of the tracheids [13]. In the present study, it was demonstrated that there were significant positive correlations between IAA levels in cambial-region tissues and the number of 
tracheids formed during late season in hinoki and slash pine (Fig. 5). In contrast, no consistent trend in the seasonal variations of IAA levels among the three conifer species was recognized in the transition from earlywood to latewood formation (Fig. 1 and Fig. 3). The role of IAA in sugi reported in our previous study [13] was also recognized in hinoki and slash pine. In the present study, it was demonstrated that IAA levels were related to cell division, but not to the transition from earlywood to latewood in three conifer species.

In this study, we demonstrated that there were speciesspecific seasonal variation patterns in IAA levels among three conifer species with inherently different wood densities, and that IAA played a role in cell division during late season. Our previous study revealed that the speciesspecific characteristics in annual ring formation affected the inherent differences in wood density among the three conifers [6]. Based on these results, we hypothesized that the species-specific seasonal variation patterns in IAA levels might affect these inherent differences in wood density. If our hypothesis is true, the seasonal ratio of the IAA levels (late/early season) might affect the inherent differences in wood density among the three conifers. As shown in Fig. 7, there was a close relationship between the seasonal ratio of IAA levels (late/early season) and the wood density among the three conifer species. Therefore, it was assumed that high levels of IAA in the late season induced active latewood formation, and then increased the wood density (Fig. 7) and mechanical properties of the wood through the development of thick cell walls, a narrow radial diameter of the cell lumen, and a small MFA in the latewood. It was very interesting that species-specific seasonal variation patterns in IAA levels might affect the species-specific seasonal annual ring formation patterns, and consequently the wood density and

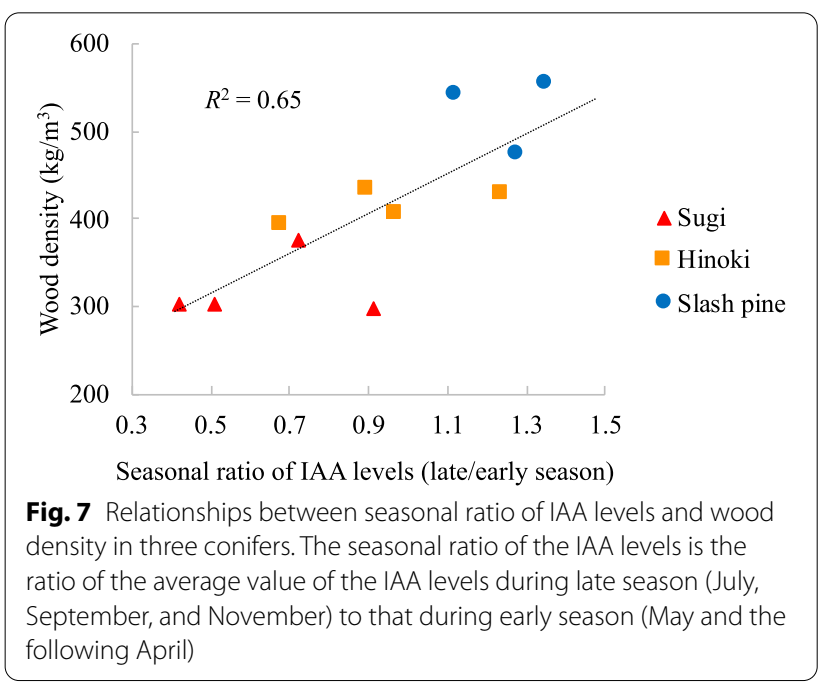

mechanical properties. However, the seasonal ratio of IAA levels could not explain the variation of wood density within the same species, especially in hinoki in Fig. 7. In this study, we used sample trees grown in the same stand with an initial tree density of 2500-3000 trees/ ha. However, different results might be obtained from sample trees grown in a stand with a lower tree density. Hinoki trees with greater radial growth had lower wood density and lower mechanical properties [23], suggesting that hinoki trees grown at a lower tree density might show different annual ring formation and seasonal variation patterns in IAA levels. Lower tree density will help reduce the cost of reforestation for sugi and hinoki trees. More precise studies with larger number of samples on each conifers are needed.

As previously described, MFA, in addition to density, is a very important anatomical parameter for determining the mechanical properties of wood. The MFA in sugi varied seasonally in each annual ring, with large MFAs in the earlywood and small MFAs in the latewood, although the MFA of hinoki showed relatively constant seasonal variation within each annual ring [30]. The MFA of latewood in the mature wood of slash pine (average value: 18.4 degrees [6]) was relatively larger than those in sugi cultivars (average value: 13.3 degrees [31]) and hinoki (average value: 10.4 degrees [23]). Based on these studies, there were species-specific characteristics of MFA variation. To elucidate the mechanism of variation of wood properties, precise studies of the relationships between the levels of plant hormones in cambial-region tissues and the inter- and intra-tree variation of MFA in coniferous plantation tree species are needed in the future.

\section{Conclusions}

In this study, it was demonstrated that there were species-specific seasonal variation patterns of IAA levels, and the IAA levels affected the number of tracheids formed in late season, and the seasonal ratio of IAA levels (late/early season) affected the inherent differences in wood density among the three conifer species. The GA4 levels had no significant effect on number of tracheids formed in the three conifers. These possible effects of the seasonal variation of IAA levels on annual ring formation were assumed to be very important for the production of logs for structural use, although more precise studies are needed to evaluate the effects of plant hormones on wood properties. In a future study, we will elucidate the effects of plant hormones on the intra- and inter-tree variation of MFA in conifers.

\section{Abbreviations}

MFA: Microfibril angle; IAA: Auxin, indole acetic acid; GA4: Gibberellin A4; $\mathrm{DBH}$ : Diameter of the trees at breast height; $\mathrm{H}$ : Tree height; $\mathrm{H} / \mathrm{D}$ ratio: 
Height-to-diameter ratio; LC/MS: Liquid chromatography/mass spectrometry; D2-IAA: Deuterium-labeled IAA; D2-GA4: Deuterium-labeled GA4; Test period I: The period from the initiation of xylem formation to May; Test period III: The period from July to September; Test period IV: The period from September to November; Test period $\mathrm{V}$ : The period from the initiation of the next annual ring formation to the next April.

\section{Acknowledgements}

The authors would like to thank Mr. Takahiro Nagai and Mr. Kodai Takeda for their contributions to the data collection.

\section{Authors' contributions}

YK designed this study and examined the IAA and GA4 amounts and annual ring formation in three conifer species, and was a major contributor in writing the manuscript. KT contributed to the experimental method and derived the hypothesis in this study. TT contributed to the discussion of the obtained results. All authors have read and approved the final manuscript.

\section{Funding}

No funding was received.

\section{Availability of data and materials}

Not applicable.

\section{Declarations}

\section{Competing interests}

The authors declare that they have no competing interests.

\section{Author details}

${ }^{1}$ Division of Forest and Environmental Science, Faculty of Agriculture, University of Miyazaki, Miyazaki 889-2192, Japan. ${ }^{2}$ Institurte of Wood Technology, Akita Prefectural University, Noshiro 016-0876, Japan.

Received: 20 January 2021 Accepted: 1 June 2021

Published online: 10 June 2021

\section{References}

1. Evans R, llic J (2001) Rapid prediction of wood stiffness from microfibril angle and density. For Prod J 51:53-57

2. Yang JL, Evans R (2003) Prediction of MOE of eucalypt wood from microfibril angle and density. Holz Roh Werkstoff 61:449-452

3. Lachenbruch B, Johnson GR, Downes GM, Evans R (2010) Relationships of density, microfibril angle, and sound velocity with stiffness and strength in mature wood of Douglas-fir. Can J For Res 40:55-64

4. Mclean JP, Evans R, Moore JR (2010) Predicting the longitudinal modulus of elasticity of Sitka spruce from cellulose orientation and abundance. Holzforschung 64:495-500

5. Yamashita K, Hirakawa Y, Nakatani H, Ikeda M (2009) Tangential and radial shrinkage variation within trees in sugi (Cryptomeria japonica) cultivars. J Wood Sci 55:161-168

6. Kijidani Y, Takata K, Ito S, Ogawa M, Nagamine M, Kubota K, Tsubomura M, Kitahara R (2011) Annual ring formation and wood properties of slash pine (Pinus elliottii) grown in southern Kyushu, Japan (in Japanese). Mokuzai Gakkaishi 57:340-349

7. Sundberg B, Little CHA (1990) Tracheid production in response to changes in the internal level of indole-3-acetic acid in 1-year-old shoots of Scots pine. Plant Physiol 94:1721-1727

8. Little CHA, Sundberg B (1991) Tracheid production in response to indole3-acetic acid varies with internode age in Pinus sylvestris stems. Trees 5:101-106

9. Larson PR (1969) Wood formation and the concept of wood quality. Yale University, New Haven, p 54

10. Savidge RA, Wareing PF (1984) Seasonal cambial activity and xylem development in Pinus contorta in relation to endogenous indol-3-ylacetic and (S)-abscisic acid levels. Can J For Res 14:676-682
11. Funada R, Kubo T, Tabuchi M, Sugiyama T, Fushitani M (2001) Seasonal variations in endogenous indole-3-acetic acid and abscisic acid in the cambial region of Pinus densiflora Sieb. et Zucc. stems in relation to earlywood-latewood transition and cessation of tracheid production. Holzforschung 55:128-134

12. Uggla C, Mellerowicz EJ, Sundberg B (1998) Indole-3-acetic acid controls cambial growth in Scots pine by positional signaling. Plant Physiol 117:113-121

13. Kijidani Y, Nagai T, Suwashita T, Tsuyama T (2017) Seasonal variations of tracheid formation and amount of auxin (IAA) and gibberellin A4 (GA4) in cambial-region tissues of mature sugi (Cryptomeria japonica) cultivar grown in a Nelder plot with different tree densities. J Wood Sci 63:315-321

14. Israelsson M, Sundberg B, Moritz T (2005) Tissue-specific localization of gibberellins and expression of gibberellin-biosynthetic and signaling genes in wood forming tissues in aspen. Plant J 44:494-504

15. Nugroho WD, Yamagishi Y, Nakaba S, Fukuhara S, Begum S, Marsoem SN, $\mathrm{Ko} \mathrm{JH}$, Jin HO, Funada R (2012) Gibberellin is required for the formation of tension wood and stem gravitropism in Acacia mangium seedlings. Ann Bot 110:887-895

16. James PB, Raymond MS (2002) Slash pine: characteristics, history, status and trends. In: Dickens ED, Barnett JP, Jokela EJ (eds) Slash pine: still growing! Jekyll Island, Georgia, April 2002, Proceedings of the Slash Pine Symposium, United States. Department of Agriculture, Forest Service Southern Research Station, Asheville

17. Harley GL, Grissino-Mayer HD, Franklin JA, Anderson C, Kose N (2012) Cambial activity of Pinus elliottii var. densa reveals influence of seasonal insolation on growth dynamics in the Florida Keys. Trees 26:1449-1459

18. Emhart VI, Martin TA, White TL, Huber DA (2006) Genetic variation in basal area increment phenology and its correlation with growth rate in loblolly and slash pine families and clones. Can J For Res 36:961-971

19. Roth BE, Jokela EJ, Martin TA, Huber DA, White TL (2007) Genotype x environment interactions in selected loblolly and slash pine plantations in the Southeastern United States. For Ecol Manage 238:175-188

20. Li X, Huber DA, Powell GL, White TL, Peter GF (2007) Breeding for improved growth and juvenile corewood stiffness in slash pine. Can J For Res 37:1886-1893

21. Mcalister RH, Clark IIIA, Saucier JR (1997) Effect of initial spacing on mechanical properties of lumber sawn from unthinned slash pine at age 40. For Prod J 47:107-109

22. Jokela EJ, Martin TA, Vogel JG (2010) Twenty-five years of intensive forest management with southern pines: important lessons learned. J For 108:338-347

23. Kijidani Y, Kawasaki Y, Matsuda D, Nakazono F, Hayakawa M, Mutaguchi H, Sakagami H (2014) Tree heights in the ring-formed years affect microfibril angles in the rings from juvenile to mature wood at breast height in hinoki trees (Chamaecyparis obtusa). J Wood Sci 60:381-388

24. Kijidani Y, Fujii Y, Kimura K, Fujisawa Y, Hiraoka Y, Kitahara R (2012) Microfibril angle and density of hinoki (Chamaecyparis obtusa) trees in 15 half-sib families in a progeny test stand in Kyushu, Japan. J Wood Sci 58:195-202

25. Kijidani Y, Sakai N, Kimura K, Fujisawa Y, Hiraoka Y, Matsumura J, Koga S (2012) Termite resistance and color of heartwood of hinoki (Chamaecyparis obtusa) trees in 5 half-sib families in a progeny test stand in Kyushu, Japan. J Wood Sci 58:471-478

26. Kijidani Y, Ohshiro N, Matsumura J, Koga S (2014) Effects of crown length on indole acetic acid (IAA) amounts in cambial region tissues in lower and upper trunks of sugi cultivars (Cryptomeria japonica) in September. J Wood Sci 60:235-242

27. Funada R, Sugiyama T, Kubo T, Fushitani M (1987) Determination of indole-3-acetic acid levels in Pinus densiflora using the isotope dilution method. Mokuzai Gakkaishi 33:83-87

28. Sundberg B, Uggla C, Tuominen $H$ (2000) Cambial growth and auxin gradients. In: Savidge RA, Barnett JR, Napier R (eds) Cell and Molecular Biology of Wood Formation. Bios Scientific, Oxford, pp 169-188

29. Uggla C, Magel E, Morits T, Sundberg B (2001) Function and dynamics of auxin and carbohydrates during earlywood/latewood transition in scots pine. Plant Physiol 125:2029-2039 
30. Ohta S, Watanabe H, Matsumoto T, Tsutsumi J (1968) Studies on mechanical properties of juvenile wood I. Fibril angle and dynamic modulus of elasticity of juvenile wood in the stem of sugi trees (Cryptomeria japonica) (in Japanese). Rep Kyusyu Univ For 22:105-116

31. Kijidani Y, Kitahara R (2009) Variation of wood properties with height position in the stems of Obi-sugi cultivars (in Japanese). Mokuzai Gakkaishi 55:198-206

\section{Publisher's Note}

Springer Nature remains neutral with regard to jurisdictional claims in published maps and institutional affiliations.

\section{Submit your manuscript to a SpringerOpen ${ }^{\odot}$ journal and benefit from:}

- Convenient online submission

- Rigorous peer review

- Open access: articles freely available online

- High visibility within the field

- Retaining the copyright to your article

Submit your next manuscript at $\boldsymbol{\nabla}$ springeropen.com 